\title{
Modified schedule of vaccination with polyvalent bovine viral diarrhea virus inactivated vaccine in dairy herds - a field study
}

\author{
Tomislav Bedekovići*, Nina Krešić1, Ivana Lojkić1, Ivana Šimić1, \\ Željko Cvetnić ${ }^{1}$, and Josip Madić ${ }^{2}$

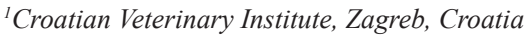 \\ ${ }^{2}$ Department of Microbiology and Infectious Diseases with Clinic, Faculty of Veterinary Medicine, \\ University of Zagreb, Zagreb, Croatia
}
BEDEKOVIĆ, T., N. KREŠIĆ, I. LOJKIĆ, I. ŠIMIĆ, Ž. CVETNIĆ, J. MADIĆ: Modified schedule of vaccination with polyvalent bovine viral diarrhea virus inactivated vaccine in dairy herds - a field study. Vet. arhiv 87, 239-248, 2017.

\section{ABSTRACT}

In order to reduce the cost of vaccination, three herds were vaccinated with polyvalent bovine viral diarrhea virus inactivated vaccine according to a modified schedule, and the specific antibody response was evaluated. In each herd only the cows and heifers were vaccinated with one dose of vaccine. Two herds (A and B) were vaccinated annually for three consecutive years. The third herd (C) was vaccinated twice with a two year interval. At the beginning of the study the herds consisted of 38,22 and 15 animals respectively. Antibody response was evaluated three and nine months after vaccination with indirect ELISA, blocking ELISA and a virus neutralization test. Within herds $\mathrm{A}$ and $\mathrm{B}$ the percentage of seropositive animals increased with each subsequent vaccination. Three months after the third vaccination more than $96 \%$ of animals in herds $\mathrm{A}$ and $\mathrm{B}$ were seropositive. Nine months after the third vaccination more than $56 \%$ of animals in herds A and B were seropositive. Three and nine months after the second vaccination the numbers of positive animals in herd $\mathrm{C}$ was $66 \%$ and $38 \%$ respectively. The obtained results show that the percentage of seropositive animals within the herds increased with each vaccination and the best detection of specific antibodies after vaccination can be achieved if a virus neutralization test is used. Also, the results show that seroprotection of cows within the herds vaccinated yearly was significantly higher $(56.52-58.82 \%)$ compared to the herd vaccinated with a two year interval $(38.88 \%)$.

Key words: bovine viral diarrhea, vaccination, modified schedule

\footnotetext{
*Corresponding author:

Tomislav Bedeković, PhD, Croatian Veterinary Institute, Savska cesta 143, 10000 Zagreb, Croatia; Phone: +385 16123605 ; E-mail: bedekovic@veinst.hr
} 
T. Bedeković et al.: Modified schedule of vaccination with polyvalent BVDV vaccine

\section{Introduction}

Bovine viral diarrhea virus (BVDV) is one of the most important common viral infections in cattle (HOUE, 1999). BVDV belongs to the genus Pestivirus within the Flaviviridae family (SIMMONDS et al., 2012). Due to the economic losses caused by BVDV, some countries have implemented control and eradication programs.

Vaccination is currently one of the control procedures for BVDV in stocker and feedlot operations (FULTON, 2005). Vaccines are based on either BVDV alone or BVDV in combination with bovine herpesvirus-1, parainfluenza virus type 3, bovine respiratory syncytial virus and bacteria (FULTON, 2005). Currently two types of vaccines are commercially present on the market within EU countries: a modified live vaccine (MLV) and a killed vaccine. MLV requires a smaller quantity of virus than the killed one, and only one dose for initial immunization (FULTON, 2005). However, the live virus in the modified live BVDV vaccine can cause immunosuppressive effects on leukocyte function (ROTH and KAEBERLE, 1983). A major concern in the use of BVDV MLV is postvaccinal disease (mucosal disease) following MLV vaccination (RIDPATH and BOLIN, 1995). Killed vaccines are generally safer in pregnant cows, but a disadvantage might be that two doses are generally required for the initial immunization (FULTON, 2005).

In order to achieve a better specific antibody response, especially when an inactivated vaccine is used, a booster vaccination is applied. This is particularly important in vaccination of calves due to their passive immunity. In that case MLV is also used; one or even two booster vaccinations are needed to achieve a higher titer of specific antibodies. However, even in this case it is not always possible to achieve a protective level of antibodies regarding transmission of the virus to the fetus. As a result, the main purpose of vaccination is prevention of acute infection. Also, even true protection against infection cannot be determined by merely measuring serum antibody levels (CORTESE et al., 1998; RIDPATH, 2003) although this is still the most rapid and cost effective method for detection of exposure to BVDV. The duration of antibody titers to various BVDV strains in calves was found to vary from 140 days to 18 months after vaccination (CORTESE et al., 1998; FULTON and BURGE, 2000).

In determination of BVDV antibodies, the most used method is ELISA because of its simplicity and time consumptions. Two types of ELISA kits are currently used: indirect and blocking (p80) ELISA. However, blocking ELISA is less suitable in detection of specific antibodies after vaccination (GRAHAM et al., 2003).

In order to determine protection and cost benefits, efficiency should be measured by field trial for each vaccine. Due to the diversity of the BVDV genotype, it is very difficult to accomplish $100 \%$ protection by vaccination, especially from the development of persistent infection. Despite that, vaccination is still the most used tool in control and eradication programs, and in prevention of acute infection. In voluntary control 
vaccination programs the main reason for refusing vaccination is the price of both the vaccine and the vaccination. The use of a polyvalent vaccine can contribute to the lower cost of vaccination. On the other hand, the use of a polyvalent vaccine can result in lower immunity response compared to a single vaccination. In addition, the possibility of vaccinating all animals within the herd in one day can significantly lower the price of vaccination.

In this study, we investigated the possibility of protecting herds against BVDV with a lower number of vaccinations and lower cost. To achieve this, a modified schedule of vaccination with polyvalent BVDV inactivated vaccine was implemented, and specific BVDV antibody response was evaluated. Antibody response after vaccination was determined by indirect ELISA (iELISA), blocking ELISA (bELISA) and a virus neutralization test (VNT). Also, evaluation was undertaken of iELISA and bELISA compared to VNT in detection of specific antibodies after vaccination.

\section{Materials and methods}

Field study. Three seronegative BVDV herds of Simmental breed cows were selected for this study. After the beginning of the study, the introduction of new animals was restricted. All three herds were dairy herds. At the start of the study, herd A consisted of 38 cattle, of which 30 were older than 6 months. Herd B consisted of 22 cattle, with 18 older than 6 months. Herd C consisted of 15 cattle, with 12 older than 6 months. This study was approved by the ethics committee of the Veterinary Faculty of the University of Zagreb; number: 251-61-01/139-11-72.

Experimental design. All animals older than six months within the three herds were vaccinated with polyvalent inactivated BVDV vaccine (Cattle Master, Pfizer). Two herds (A and B) were vaccinated in 2008, 2009 and 2010. Herd C was vaccinated in 2008 and 2010. In each herd, all heifers and cows (all animals older than six months) were vaccinated at the same time. For each vaccination, only one dose of vaccine was applied. No booster vaccination was conducted. Calves were not vaccinated. However, each calf was vaccinated when it had reached the age of 6 months (when they became heifers) by the time of the next vaccination. At the beginning of this study three calves were randomly selected from each herd and were used as a control group. These calves stayed in the herd throughout the study and were not vaccinated. These calves were not included in the statistical analysis.

Sampling. Blood samples were taken on the day of vaccination. From herds A and B blood samples were also taken three and nine months after each vaccination. From herd $\mathrm{C}$ blood samples were taken three, nine, 15 and 21 months after the first vaccination and three and nine months after the second vaccination. 
Virus testing. In order to obtain virus status, all samples were tested for virus presence by antigen enzyme-immunosorbent assay (Herdchek BVDV Ag/Serum Plus, IDEXX, Switzerland). Sera were tested according to the manufacturer's recommendations.

Antibody testing. Antibody response against BVDV was determined using two commercial ELISA kits and a virus neutralization test. The following commercial ELISA kits were used: Herd Check BVDV Ab (IDEXX, Switzerland) and PrioCHECK BVDV $\mathrm{Ab}$ (Prionics, Switzerland). Tests were performed according to the manufacturers' recommendations. The virus neutralization test was performed according to the Manual for Terrestrial Animals (OIE, 2008). Briefly, sera were inactivated at $56{ }^{\circ} \mathrm{C}$ for $30 \mathrm{~min}$. Two-fold serial dilutions of sera ranging from 1:2 to 1:256 were made in microtiter plates. For each reference strain, two wells were used. One hundred TCID50 of the reference strains (NADL - supplied by Friedrich Loeffler Institute, Insel Riems, Germany) were added to duplicate columns. In Croatia only genotype 1 has been confirmed and as a result the antibody response was determined only against genotype 1. After 1 hour of incubation at $37^{\circ} \mathrm{C}$, Madin Darby bovine kidney cells were added and the plates were incubated for four days at $37{ }^{\circ} \mathrm{C}$. After incubation, the presence of viruses was confirmed using BVDV specific monoclonal antibodies (BVDV specific monoclonal antibodies, VLA, Weybridge, UK) and antimouse rabbit antibodies (Fluorescein isothiocyanate conjugate anti-mouse antibodies, Sigma-Aldrich, St.Louis, USA). Even though NADL strain is a cytopathic strain, immunofluorescence staining was applied. The reason for this is the possibility of differentiation between citotoxicity in the cell culture and positive results, especially at lower dilutions. Antibody titers of 1:2 and higher were considered positive.

All calves in the control group stay seronegative throughout the study.

Statistic analysis. Sensitivity and specificity were calculated using the following formula: sensitivity $=[$ true positives $/$ (true positives + false negatives $)] \times 100$; specificity: true negative/(true negatives + false positives) $\times 100$.

\section{Results}

Virus testing. All herds remained negative for the virus throughout the study.

Antibody testing. At the beginning of the study all the animals were seronegative for antibodies against BVDV when tested by VNT and both ELISA kits: Herd Check BVDV Ab (IDEXX, Switzerland) and PrioCHECK BVDV Ab (Prionics, Switzerland). Three and nine months after the first vaccination in herd A immunity tested by VNT was $68.42 \%$ and $39.47 \%$ respectively. After the second vaccination the immunity of the herd tested by VNT was $83.33 \%$ and $58.82 \%$. After the third vaccination immunity was $95 \%$ and $60 \%$. Antibody response within herd A in vaccinated cattle and data about colostrum antibodies within calves are presented in Table 1 . Three and nine months after the first vaccination in herd B immunity was $59.09 \%$ and $40 \%$ respectively. After the 
second vaccination immunity was $79.16 \%$ and $52 \%$. After the third vaccination immunity was $92.85 \%$ and $56 \%$. Antibody response within herd B in vaccinated cattle and data about colostrum antibodies in calves are presented in Table 2. Three and nine months after the first vaccination, in herd $\mathrm{C}$ immunity was $60 \%$ and $38.46 \%$ respectively. 15 and 21 months after the first vaccination immunity was $26.66 \%$ and $16.66 \%$. After the second vaccination immunity was $65 \%$ and $38.88 \%$. Antibody response within herd C in vaccinated cattle and data about colostrums antibodies in calves are presented in Table 3. The specificity and sensitivity of iELISA and bELISA compared to VNT were calculated for each herd.

Table 1. The number of positive animals within herd A three and nine months after the first, second and third vaccinations

\begin{tabular}{|l|c|c|c|c|c|c|}
\hline \multicolumn{4}{|c|}{ Cows and heifers } & \multicolumn{3}{c|}{ Calves } \\
\hline $\begin{array}{l}\text { Time of } \\
\text { sampling }\end{array}$ & iELISA & bELISA & VNT & iELISA & bELISA & VNT \\
\hline $1^{\text {st }}$ vacc. & & & & & & \\
\hline 3 months & $13 / 30$ & $3 / 30$ & $26 / 30$ & $0 / 8$ & $0 / 8$ & $0 / 8$ \\
\hline 9 months & $6 / 30$ & $1 / 30$ & $15 / 30$ & $0 / 8$ & $0 / 8$ & $0 / 8$ \\
\hline $2^{\text {nd }}$ vacc. & & & & & & \\
\hline 3 months & $23 / 30$ & $4 / 30$ & $28 / 30$ & $1 / 6$ & $0 / 6$ & $2 / 6$ \\
\hline 9 months & $9 / 28$ & $2 / 28$ & $17 / 28$ & $2 / 6$ & $0 / 6$ & $3 / 6$ \\
\hline $3^{\text {rd }}$ vacc. & & & & & & \\
\hline 3 months & $32 / 36$ & $5 / 36$ & $36 / 36$ & $2 / 4$ & $1 / 4$ & $2 / 4$ \\
\hline 9 months & $11 / 34$ & $1 / 34$ & $20 / 34$ & $2 / 6$ & $0 / 6$ & $4 / 6$ \\
\hline
\end{tabular}

Table 2. The number of positive animals within herd B three and nine months after the first, second and third vaccinations

\begin{tabular}{|l|c|c|c|c|c|c|}
\hline \multicolumn{5}{|c|}{ Cows and heifers } & \multicolumn{3}{c|}{ Calves } \\
\hline $\begin{array}{l}\text { Time of } \\
\text { sampling }\end{array}$ & iELISA & bELISA & VNT & iELISA & bELISA & VNT \\
\hline $1^{\text {st }}$ vacc. & & & & & & \\
\hline 3 months & $6 / 18$ & $1 / 18$ & $13 / 18$ & $0 / 4$ & $0 / 4$ & $0 / 4$ \\
\hline 9 months & $2 / 18$ & $0 / 18$ & $8 / 18$ & $0 / 2$ & $0 / 2$ & $0 / 2$ \\
\hline $2^{\text {nd }}$ vacc. & & & & & & \\
\hline 3 months & $14 / 22$ & $3 / 22$ & $17 / 22$ & $1 / 2$ & $0 / 2$ & $2 / 2$ \\
\hline
\end{tabular}


T. Bedeković et al.: Modified schedule of vaccination with polyvalent BVDV vaccine

\begin{tabular}{|l|c|c|c|c|c|c|}
\hline 9 months & $5 / 22$ & $1 / 22$ & $10 / 22$ & $0 / 3$ & $0 / 3$ & $3 / 3$ \\
\hline $3^{\text {rd }}$ vacc. & & & & & & \\
\hline 3 months & $21 / 26$ & $4 / 26$ & $25 / 26$ & $0 / 2$ & $0 / 2$ & $1 / 2$ \\
\hline 9 months & $7 / 23$ & $0 / 23$ & $13 / 23$ & $1 / 2$ & $1 / 2$ & $1 / 2$ \\
\hline
\end{tabular}

Table 3. The number of positive animals within herd $\mathrm{C}$ three, nine, fifteen and twenty-one months after the first vaccination; and three and nine months after the second vaccination

\begin{tabular}{|l|c|c|c|c|c|c|}
\hline \multicolumn{4}{|c|}{ Cows and heifers } & \multicolumn{3}{c|}{ Calves } \\
\hline $\begin{array}{l}\text { Time of } \\
\text { sampling }\end{array}$ & iELISA & bELISA & VNT & iELISA & bELISA & VNT \\
\hline $1^{\text {st }}$ vacc. & & & & & & \\
\hline 3 months & $4 / 12$ & $2 / 12$ & $9 / 12$ & $0 / 3$ & $0 / 3$ & $0 / 3$ \\
\hline 9 months & $2 / 11$ & $0 / 11$ & $5 / 11$ & $0 / 2$ & $0 / 2$ & $0 / 2$ \\
\hline 15 months & $2 / 14$ & $0 / 14$ & $4 / 14$ & $0 / 1$ & $0 / 1$ & $0 / 1$ \\
\hline 21 months & $1 / 15$ & $0 / 15$ & $3 / 15$ & $0 / 3$ & $0 / 3$ & $0 / 3$ \\
\hline $2^{\text {nd }}$ vacc. & & & & & & \\
\hline 3 months & $4 / 18$ & $1 / 18$ & $12 / 18$ & $1 / 2$ & $0 / 2$ & $1 / 2$ \\
\hline 9 months & $3 / 18$ & $0 / 18$ & $7 / 18$ & $0 / 0$ & $0 / 0$ & $0 / 0$ \\
\hline
\end{tabular}

Statistical analysis The sensitivity and specificity of indirect and blocking ELISA compared to VNT are presented in Table 4.

Table 4. The sensitivity and specificity of indirect ELISA (iELISA) and blocking ELISA (bELISA) within herds compared to the virus neutralization test (VNT)

\begin{tabular}{|c|c|c|c|c|}
\hline \multirow{2}{*}{ Herd } & \multicolumn{2}{|c|}{ iELISA } & \multicolumn{2}{c|}{ bELISA } \\
\cline { 2 - 5 } & Sensitivity (\%) & Specificity (\%) & Sensitivity (\%) & Specificity (\%) \\
\hline A & 74.63 & 100 & 52.94 & 100 \\
\hline B & 62.33 & 100 & 51.79 & 100 \\
\hline C & 63.07 & 100 & 51.89 & 100 \\
\hline
\end{tabular}

\section{Discussion}

Vaccination is still the most commonly used tool in BVDV control and eradication programs. Two different vaccines are currently used against BVDV: live modified and inactivated vaccine. Due to the applicability BVD vaccine is very often used as part of polyvalent vaccines. The assessment of vaccine quality includes several points 
(FULTON, 2005). These include a field study and a cost benefit study. The field study includes assessment of antibody response and a challenge trial. Even though it does not have absolute value, determination of specific antibodies is still the most common and economically most effective method for evaluation of exposure to BVDV. In that sense, it is very important to have good diagnostic tools. In determination of BVDV specific antibodies, the most frequently used method is ELISA because of its simplicity and duration. Two types of ELISA kits are currently used: indirect and blocking (p80) ELISA. It has been reported that some, but not all, inactivated BVDV vaccines do not induce detectable antibodies against the NS3 (p80) protein (GRAHAM et al., 2003). These findings were confirmed in other studies (ALVAREZ et al., 2012; MAKOSCHEY et al., 2007; RAUE et al., 2010). According to previous studies, indirect ELISA was very good in the detection of BVDV antibodies after vaccination (RAUE et al., 2010). According to the manufacturer, the specificity and sensitivity of iELISA kit are $99.5 \%$ and $96.3 \%$ compared to VNT. In our case the sensitivity and specificity of indirect ELISA was $71.92 \%$ and $100 \%$ compared to VNT. The sensitivity and specificity of bELISA was $52.75 \%$ and $100 \%$. Due to its high cost VNT is rarely used for evaluation of specific BVDV antibody response after vaccination. However, our findings implicate that only VNT can provide accurate assessment of antibody response after vaccination.

In vaccination against BVDV different protocols are used. The protocol depends on the production type. The standard protocol of vaccination of dairy herds includes vaccination of calves and annual vaccination of heifers and cow. The vaccination of calves includes two or three vaccinations with three week intervals depending on the age at the first vaccination. Vaccination of heifers includes a first vaccination and booster vaccinations three weeks and six months after the first one. With this vaccination schedule, three weeks after the second vaccination all animals were positive for BVDV antibodies (ALVAREZ et al., 2012). However, for cattle as herd animals herd immunity is very important. Herd immunity implies that overall immunity of the herd is greater than the sum of immunity enjoyed by individual animals in the herd (THURMOND, 2005). Furthermore, immunity to most infectious agents is not likely to be absolute (THURMOND, 2005). This is particularly true in the case of BVDV because of the presence of high antigenic diversity among BVDV strains (DUBOVI, 1992; RIDPATH et al., 2003) and the possibility of persistent infection. Also, booster vaccinations affect the final price and the cost benefits of vaccination. Ideally, satisfactory protection of the herd is achieved with a minimal number of vaccination. However, BVD is a specific disease because of persistent infection, and implementation of vaccination without other measures (culling of persistently infected animals) is not sufficient for eradication of the disease.

One approach to estimating the rate of force of transmission and herd immunity is the use of a basic reproduction number $\left(\mathrm{R}_{0}\right)$, referred to as $\mathrm{R}$-not, which represents the 
expected number of new infections resulting from contact with an infectious index case animal (THURMOND, 2005). The R-not depends on the infectiousness of the virus strain $(\beta)$, the number of adequate contacts per time period $(k)$ and the duration of the infectious period. If $\mathrm{R}_{0}$ is 4 then the proportion of the herd that will need to be effectively immunized by vaccination to prevent transmission from acutely infected animals is $75 \%$. If the $R_{0}$ is 2 , rather than 4 , only $50 \%$ of the herd would need to be immunized (THURMOND, 2005). Experience has shown that vaccination is not sufficient for elimination of persistent infection from the herd. However, with vaccination, acute infection can be reduced. In the case of acute infection $\mathrm{R}_{0}$ can be calculated. Let us suppose that the incidence is $0.5 \%$ per day for weaned calves (RUSH et al., 2001), $k$ is about 25 contacts per day, and the prevalence of PI animals is $1 \%$, and $\beta$ is 0.02 . After substituting this value into the formula for $\mathrm{R}_{0}$ and assuming an infectious period of 4 days, $\mathrm{R}_{0}=2$. This means that acute infection can be prevented if $50 \%$ of herd is protected.

In our study, three months after the first vaccination, more than $50 \%$ of animals were positive for specific antibodies. Nine months after the first vaccination in herds A and B around $40 \%$ of animals were positive for specific antibodies. However, after the second and third vaccinations, the number of positive animals within the herd increased. Three months after the third vaccination, in herds A and B the number of positive animals was $95 \%$ and $92 \%$ respectively. Nine months after the third vaccination, in herds A and B the number of positive animals was $60 \%$ and $56 \%$ respectively. This implies that the duration of immunity in vaccinated cattle is an individual characteristic. Also, not only did the number of positive animals fall after nine months, but the level of antibodies also decreased within some positive animals (data are not shown). The influence of the decreasing protective antibody levels should be further evaluated by a challenge trial. This is particularly true if it is known that in some cases vaccinated animals without measurable antibodies were protected after a challenge (CORTESE et al., 1998). Nevertheless, continual annual vaccination of heifers and cows in dairy herds has the potential to provide satisfactory immunity of the herd. Furthermore, with this vaccination schedule each heifer will be vaccinated before breeding. This is very important because of the possibility of establishment of persistent infection.

In herd $\mathrm{C}$ antibody levels did not increase after the second vaccination. Also, the number of positive animals two years after vaccination was below $50 \%$. However, even after 21 months antibodies were detected in some animals. This indicated that this schedule of vaccination is not applicable to herd protection. In addition, this finding confirms individual differences in the duration of immunity.

In conclusion, the response of specific BVDV antibodies after vaccination using a modified schedule was very good. According to this schedule each heifer will be vaccinated before breeding in order to prevent persistent infection. After the second 
vaccination the level of herd immunity did not drop below $50 \%$ for one year. Moreover, after each subsequent vaccination the percentage of positive animals increased. This schedule of vaccination shows that it can provide identical protection after infection with BVDV as a standard scheme, but with lower cost. However, further studies, especially a challenge trial, are needed to confirm that possibility. Also, it should be noted that this vaccine does not provide foetal protection even after vaccination according to the regular schedule. According to this study for assessment of antibody response after vaccination, VNT should be used.

\section{References}

ALVAREZ, M., J. DONATE, B. MAKOSCHEY (2012): Antibody responses against non-structural protein 3 of bovine viral diarrhoea virus in milk and serum samples from animals immunised with an inactivated vaccine. Vet. J. 191, 371-376.

CORTESE, V., K. H. WEST, L. E. HASSARD, S. CARMAN, J. A. ELLIS (1998): Clinical and immunologic response of vaccinated and unvaccinated calves to infection with a virulent typeII isolate of bovine viral diarrhea virus. J. Am. Vet. Med. Assoc. 213, 1312-1319.

DUBOVI, E. J. (1992): Genetic diversity and BVD virus. Comp. Immun. Microbiol. Inf. Dis. 15, $155-162$.

FULTON, R. W. (2005): Vaccines. In: Bovine Viral Diarrhea Virus. Diagnosis, Management, and Control. $1^{\text {st }}$ ed. (Goyal S. M., J. F. Ridpath, Eds.), Blackwell, Iowa, pp. 209-222.

FULTON, R. W., L. J. BURGE (2000): Bovine viral diarrhea virus types 1 and 2 antibody response in calves receiving modified live virus or inactivated vaccines. Vaccine 19, 267-274.

GRAHAM, D. A., A. GERMAN, K. MAWHINNEY, E. A. GOODALL (2003): Antibody responses of naïve cattle to two inactivated bovine viral diarrhoea virus vaccines, measured by indirect and blocking ELISAs and virus neutralisation. Vet. Rec. 152, 795-800.

HOUE, H. (1999): Epidemiological features and economical importance of bovine viral diarrhoea virus (BVDV) infections. Vet. Microbiol. 64, 135-144.

MAKOSCHEY, B., D. SONNEMANS, J. M. BIELSA, P. FRANKEN, M. MARS, L. SANTOS, M. ALVAREZ (2007): Evaluation of the induction of NS3 specific BVDV antibodies using a commercial inactivated BVDV vaccine in immunization and challenge trials. Vaccine 25, 6140-6145.

OIE (2008): OIE/Office Internationale des Epizooties. Rabies. In: Manual for diagnostic tests and vaccines for terrestrial animals. OIE, Paris. http://www.oie.int/fileadmin/Home/eng/Health_ standards/tahm/2.04.08_BVD.pdf.

RAUE, R., S. S. HARMEYER, I. A. NANJIANI (2010): Antibody responses to inactivated vaccines and natural infection in cattle using bovine viral diarrhoea virus ELISA kits: assessment of potential to differentiate infected and vaccinated animals. Vet. J. 187, 330-334. 
T. Bedeković et al.: Modified schedule of vaccination with polyvalent BVDV vaccine

RIDPATH, J. F. (2003): BVDV genotypes and biotypes: practical implication for diagnosis and control. Biologicals 31, 127-131.

RIDPATH, J. F., S. R. BOLIN (1995): Delayed onset postvaccinal mucosal disease as a result of genetic recombination between genotype 1 and genotype 2 BVDV. Virology 212, 259-262.

RIDPATH, J. F., J. D. NEILL, J. ENDSLEY, J. A. ROTH (2003): Effect of passive immunity on the development of a protective response against bovine viral diarrhea virus in calves. Am. J. Vet. Res. 64, 65-69.

ROTH, J. A., M. L. KAEBERLE (1983): Supression of neutrophil and lymphocyte function induced by a vaccinal strain of bovine viral diarrhea virus with and without the administration of ACTH. Am. J. Vet. Res. 44, 2366-2372.

RUSH, D. M., M. C. THURMOND, C. MUNOZ-ZANZI, S. K. HIETALA (2001): Descriptive epidemiology of postnatal bovine viral diarrhea virus infection in intensively managed dairy heifers. J. Am. Vet. Med. Assoc. 219, 1426-1431.

SIMMONDS, P., P. BECHER, M. S. COLLET, E. A. GOULD, F. X. HEINZ, G. MEYERS, T. MONATH, A. PLETNEV, C. M. RICE, K. STIASNY, H. J. THIEL, A. WEINER, J. BUKH (2012): Family Flaviviridae. In: King AMQ Virus Taxonomy. Ninth report of the International Committee on Taxonomy of Viruses. (King, A. M. Q., M. J. Adams, E. B. Carstens, E. J. Lefkowitz, Eds.), Elsevier, Oxford, pp. 1003-1020.

THURMOND, M. C. (2005): Virus Transmission. In: Bovine Viral Diarrhea Virus. Diagnosis, Management, and Control. $1^{\text {st }}$ ed. (Goyal S. M., J. F. Ridpath, Eds.), Blackwell, Iowa, pp. 91-104.

Received: 13 January 2016

Accepted: 9 September 2016

\section{BEDEKOVIĆ, T., N. KREŠIĆ, I. LOJKIĆ, I. ŠIMIĆ, Ž. CVETNIĆ, J. MADIĆ: Modificirana shema cijepljenja stada mliječnih goveda polivalentnim cjepivom protiv virusnog proljeva goveda - terensko istraživanje. Vet. arhiv 87, 239-248, 2017. \\ SAŽETAK}

Da bi se procijenila mogućnost smanjenja troškova cijepljenja, tri su stada goveda cijepljena protiv virusnog proljeva goveda polivalentnim cjepivom prema modificiranoj shemi. U dva stada (38 i 22 goveda) sve krave i junice cijepljene su jednom godišnje tri godine uzastopce. U trećem stadu (15 goveda) cijepljene su sve krave i junice prve i treće godine. Uspješnost cijepljenja provjeravala se imunoenzimnim testom i virusneutralizacijskim testom određujući specifična protutijela u uzorcima krvnih seruma. Tri mjeseca nakon trećeg cijepljenja unutar prva dva stada postotak serološki pozitivnih goveda bio je veći od $96 \%$. Devet mjeseci nakon trećeg cijepljenja unutar prva dva stada postotak serološki pozitivnih goveda bio je veći od $56 \%$. U trećem stadu postotak serološki pozitivnih goveda tri i devet mjeseci nakon trećeg cijepljenja bio je $66 \%$ i $38 \%$. Dobiveni rezultati pokazuju da se postotak serološki pozitivnih grla unutar svakog stada svakim sljedećim cijepljenjem povećao te da se procjena uspješnosti cijepljenja najbolje može odrediti virus-neutralizacijskim testom.

Ključne riječi: virusni proljev goveda, cijepljenje, modificirana shema 